\title{
Organization of residential areas focused on walking and using low-speed individual vehicles
}

\author{
Olga Leptyukhova ${ }^{1^{*}}$, Daria Bibartceva ${ }^{1}$ \\ ${ }^{1}$ National Research Moscow State University of Civil Engineering, Yaroslavskoye sh., 26, Moscow, \\ 129337, Russia
}

\begin{abstract}
To create a comfortable urban environment, authorities are currently working with the population to reduce the specific share of trips by private car and to encourage the use of alternative modes of transportation, including walking, using low-speed individual vehicles as well. The feasibility of such actions is confirmed by numerous studies of the current urban environment, formed based on the universal accessibility of a private car. Car is a personal vehicle, stored near the place of residence. In the conditions of dense development of large cities, formed according to the rules that do not take into account the ownership of a car by the bulk of the population, as well as modern multi-story buildings in the context of a shortage of land resources, the population is faced with the problem of congestion of local territories with private cars, which leads to conflicts between neighbors. In these conditions, the urgent problem of organizing residential elements of the planning structure focused on pedestrian movements and movement using low-speed individual vehicles. This raises the question of the reorganization of the living environment and the identification of the territorial reserves for changes. This article presents the results of a study of the dense development of residential areas to identify the possibilities of its reorganization based on the principles of pedestrian accessibility and accessibility for low-speed individual vehicles. For research, the design method was used. This method made it possible to establish the quantitative value of territorial resources that are possible for redistribution according to their functional purpose, provided that the intensity of use of the territory corresponds to the standards of urban planning.
\end{abstract}

\section{Introduction}

The purpose of the study is to create a comfortable urban environment in densely built-up residential areas, focused on walking and using low-speed personal vehicles (hereinafter LSPV), subject to the standards of urban planning.

The subject of the study is the reorganization of built-up residential areas based on the principles of pedestrian and LSPV accessibility.

Object of study - densely built-up residential areas of a large city.

The last annual Address of the President of Russia to the Federal Assembly in January

${ }^{*}$ Corresponding author: oy-2@mail.ru 
2020 announced the implementation of large-scale social reforms aimed at improving the quality of life in all spheres of life of the Russian population. Improvements should directly affect the formation of the urban development environment in which most people carry out their daily activities. A national project "Housing and Urban Environment" was launched and adopted for implementation, one of the goals of which is "to increase the comfort of the urban environment, increase the urban environment quality index by $30 \%$, and halve the number of cities with an unfavorable environment following this index". The government of the constituent entities of the Russian Federation approved state programs to form a modern comfortable urban environment." According to the Ministry of Construction of Russia, the bulk of the funds is planned to create a comfortable environment for domestic territories. Achieving the goal set at the state level can be decided in two ways: by overhauling the existing landscaping of residential areas, followed by tight control over maintaining it in order, or by conducting a deep reorganization of urban residential spaces, taking into account the new social needs of the population and the influence of modern urban planning factors.

With a change in the standard of living of the population, people's needs change: with an increase in the level of well-being, people become more demanding, more careful in their choice and attentive to little things. So the needs of the urban population of countries with higher levels of GDP differ from the needs of the population of Russian cities. In this regard, it is interesting to compare people's requirements for purchased residential real estate in Russia and abroad (Table 1).

Table 1. Factors affecting the choice / value of real estate

\begin{tabular}{|l|l|}
\hline \multicolumn{2}{|l|}{ Factors affecting the choice / value of real estate } \\
\hline $\begin{array}{l}\text { USA (Portland State University study, } \\
\text { "Portland Green Loop economic } \\
\text { analysis") }\end{array}$ & $\begin{array}{l}\text { Russia (Research of the Yandex service from } \\
08 / 13 / 2019)\end{array}$ \\
\hline $\begin{array}{l}\text { 1. Characteristics of residential real } \\
\text { estate: apartment size, age, the tax rate }\end{array}$ & 1. Price category \\
\hline $\begin{array}{l}2 . \quad \text { Regional and territorial } \\
\text { characteristics: public school (like } \\
\text { public schools in America are free, and } \\
\text { kindergartens are paid), quality, safety, } \\
\text { distance to the center, economic } \\
\text { conditions of the district }\end{array}$ & $\begin{array}{l}\text { 2. Transport accessibility, proximity to the city } \\
\text { work, study, residence relatives. }\end{array}$ \\
\hline 3. Accessibility for cycling and walking & $\begin{array}{l}\text { 3. Apartment area (depending on the number of } \\
\text { people in the family), number of rooms, } \\
\text { apartment layout }\end{array}$ \\
\hline $\begin{array}{l}\text { 4. Reliability of the builder (Actual for those } \\
\text { who buy housing at the construction stage. This } \\
\text { is due to the negative experience of shared } \\
\text { financing of construction, as well as the } \\
\text { inconsistency of the finished product with the } \\
\text { declared one before the start of construction in } \\
\text { advertising booklets) }\end{array}$ \\
\hline \begin{tabular}{l} 
5. Ecological situation in the area \\
\hline
\end{tabular}
\end{tabular}

According to a study by Portland Green Loop economic analysis at Portland State University, the choice of residential real estate in the United States by buyers and the determination of value by developers depends on factors such as accessibility, primarily associated with walking and cycling. The choice of Russians - buyers of residential real estate according to data on August 13, 2019, published by Yandex, is somewhat different from Americans, and the factor of walking and cycling accessibility of the territory is not 
included in the top-main factors. This is due to the current development of Russian society, in which the car plays an important role, being not only a means of transportation but also an indicator of the well-being of its owner. The choice of movement in a personal car of Russians is also associated with the peculiarity of climatic conditions, as well as the unreadiness of the city infrastructure to provide pedestrian movements and movements on the LSPV. In the United States, the problem of adapting the urban environment for walking and cycling has been dealt with for more than 10 years. And there is a lot of experience in organizing such urban spaces. Besides, North American and Western European residents are more informationally prepared for innovations and changing the priority in using a private car. [2-6]

Recently, a new segment of residential real estate has appeared on the Russian real estate market - housing with the so-called "courtyards without cars". Developers made a new marketing move and attract the attention of buyers with new planning features of residential development. The essence of such planning methods is to limit access to the local area of personal vehicles that are not considered residents of a dwelling house or group of houses. These actions indicate an increase in consumer requirements for the organization of the outdoors territory, its humanization.

At its core, this is a very useful way to organize the city environment for the functioning of the city. The transformation of the urban environment to ensure comfortable walking movements has many positive consequences [7-14]. Residential areas with limited access for private cars have several advantages, such as reducing the need for land resources at the stage of development of the territory and saving money on the construction and maintenance of infrastructure for road transport, reducing traffic flows in the city by reducing the use of a personal car, increasing demand for services public transport, as well as the possibility of forming a more compact development with safe, green, noise-protected attractive courtyards spaces. [15-16]

Also, it has been proven that investment in the city's bicycle and pedestrian infrastructure revitalize the local economy. This is due to the fact that for pedestrians and users of LSPV traveling at low speeds, objects of the urban environment are more accessible. [17-20] Table 2 shows the results of studies of the revenue of cultural and commercial institutions from visits by different categories of users: motorists, cyclists, pedestrians. On average, the amount spent by pedestrians or cyclists is approximately equal to or greater than that of motorists, and the frequency of visits was higher than that of motorists.

If the money will be spent in the area of residence, it can be expected that the economy of such a region will develop more intensively. This is the incentive to create a pedestrian and infrastructure for LSPV for local authorities.

Besides, according to the same Portland Green Loop Economic Analysis study, the cost of housing in residential buildings as a result of the organization of high-quality pedestrian and bicycle infrastructure increased from 0.05 to $7.96 \%$.

Thus, territories oriented to walking and LSPV, with other similar conditions, have great potential for economic development and are attractive for investment [1].

When organizing pedestrian traffic routes, as the most vulnerable participant in the movement, it is important to comply with the quality requirements of the organized traffic routes. [21-24]

All information mentioned above makes the problem of the reorganization of the territory of residential areas based on the principles of pedestrian and LSPV accessibility relevant.

Well-known "car free areas" are areas without a personal car in Europe: Vauban (Freiburg), Rothenburg ob der Tauber - Germany, Autofreie Mustersiedlung Floridsdorf housing project - Austria, Louvain-la-Neuve - Belgium, Cardiff - UK; Sacramento 
(California), Portland (Oregon), Memphis (Tennessee), San Antonio (Texas) - USA, Buenos Aires - Argentina.

Table 2. Mode share and shopping frequency/spending

\begin{tabular}{|c|c|c|}
\hline City & Method & Results \\
\hline $\begin{array}{l}\text { San } \\
\text { Francisco } \\
\text { (Bent \& } \\
\text { Snga, 2009) }\end{array}$ & $\begin{array}{l}\text { Survey on } 1187 \text { people to } \\
\text { examine the spending } \\
\text { patterns of travelling to } \\
\text { downtown SF }\end{array}$ & $\begin{array}{l}\text { Driver } 16 \%, \quad \$ 88 / \text { visit, } 4 \text { days } / \mathrm{m}, \quad \$ 259 \text {; } \\
\text { Transit } 60 \% \text {, } \$ 40 / \text { visit, } 7 \text { days } / \mathrm{m}, \quad \$ 274 \text {; } \\
\text { Walker } 21 \%, \$ 47 / \text { visit, } 8 \text { days } / \mathrm{m}, \$ 291 .\end{array}$ \\
\hline $\begin{array}{l}\text { Davis } \\
\text { (Popovich \& } \\
\text { Handy, 2014) }\end{array}$ & $\begin{array}{l}\text { Two cross-sectional online } \\
\text { surveys, use binomial } \\
\text { regression model for } \\
\text { estimate frequency of } \\
\text { downtown shopping, and } \\
\text { linear regression to estimate } \\
\text { spending in downtown }\end{array}$ & $\begin{array}{l}\text { Shoppers who enjoy biking statistically } \\
\text { more frequent }(0.185) \text { shopping in } \\
\text { downtown than car uses Shoppers who bike } \\
\text { to downtown spent slightly more than car } \\
\text { uses range from } \$ 7 \text { to } \$ 12 \text { per time, however } \\
\text { not statistically significant }\end{array}$ \\
\hline $\begin{array}{l}\text { Portland } \\
\text { (Clifton et } \\
\text { al., 2012) }\end{array}$ & $\begin{array}{l}\text { Survey from customers at } \\
\text { restaurants, drinking places, } \\
\text { convenience stores and } \\
\text { supermarket patrons }\end{array}$ & $\begin{array}{l}\text { Average month spending: Supermarket: car } \\
\$ 440 \text {, bike } \$ 338 \text {, walk } \$ 386 \text {; Convenience } \\
\text { stores: car } \$ 69 \text {, bike } \$ 82 \text {, walk } \$ 65 \text {; } \\
\text { Drinking places: car } \$ 41 \text {, bike } \$ 82 \text {, walk } \\
\$ 64 \text {; Restaurants: car } \$ 41 \text {, bike } \$ 48 \text {, walk } \\
\$ 32 \text {. }\end{array}$ \\
\hline $\begin{array}{lr}\text { NY } & \text { East } \\
\text { Village } & -1 \text { st } \\
\text { and } & 2 \mathrm{nd} \\
\text { Ave9 }\end{array}$ & Install protected bike lane & $\begin{array}{l}\text { Bike and pedestrian spend are } \$ 163, \$ 158 \\
\text { per week, while drives are } \$ 143\end{array}$ \\
\hline
\end{tabular}

\section{Materials and Methods}

As a result of the analysis of foreign experience, the following basic principles of organizing the territories of residential areas with an orientation on walking and using LSPV can be distinguished:

1. Combining institutions of everyday use (schools, kindergartens, clinics, shops, catering facilities, etc.) into a single pedestrian network;

2. Maximum landscaping of the pedestrian network;

3. The inclusion of public passenger transport stops in the pedestrian network,

4. Equipping the pedestrian network with infrastructure for LSPV, small architectural forms (benches, urns), lighting devices.

5. The inclusion in the network of public spaces for events, leisure.

6. Possibility of using by people with limited mobility.

7. Secure pedestrian crossings.

One of the indicators of the quality of the organization of urban space is the ratio of normative and actual parameters of urban infrastructure.

As part of the study, it was decided to study the territorial possibilities for changing the functional purpose of sections of residential areas while ensuring their formal organization quality when arranging a comfortable urban environment based on pedestrian and LSPV movements.

The main objective of the study was to analyze the distribution of territorial resources in the balance of residential areas within the boundaries of one district, as well as to develop a plan for the architectural and planning organization of part of the territory of a residential area based on new principles, provided that the normative intensity of use of the territory is ensured. 
During the implementation of the territory reorganization project, the following tasks were set:

1. The combination of public transport routes, including metro stations, in the shortest directions by pedestrian and LSPV traffic routes.

2. Maximum landscaping of the system of continuous comfortable and safe pedestrian communications, as well as the ways of movement of LSPV users.

3. Reducing the number of intersections of the designed traffic paths with vehicle traffic paths.

4. Combining the network of commercial and cultural facilities with the main directions of pedestrian flows.

5. Reducing the width and length of driveways for the movement of personal vehicles, the exclusion of places of permanent storage of vehicles on the surface. Providing access to special vehicles.

6. Creation of the maximum possible areas for leisure and landscaping.

7. Designing taking into account the needs of people with limited mobility.

8. Implementation of regional standards for urban design.

In order to conduct the study, the choice of territory for the design experiment was carried out based on the following criteria:

1. The territorially advantageous planning position of the residential territory (the central part of the city with developed transport services, the presence of landscape dominants).

2. Dense development of the territory, including multi-story residential buildings.

3. The presence of a large number of public-business and cultural facilities in the territory.

4. Obvious problems with the organization of courtyard spaces (mainly related to the lack of parking spaces, manifested in a large number of parked vehicles outside specially equipped places).

5. Difficult traffic situation and undeveloped pedestrian network.

6. Physical and moral depreciation of infrastructure.

Based on the above criteria, elements of planning infrastructure for residential use were selected - candidates for participation in the study (Figures 1,2,3).

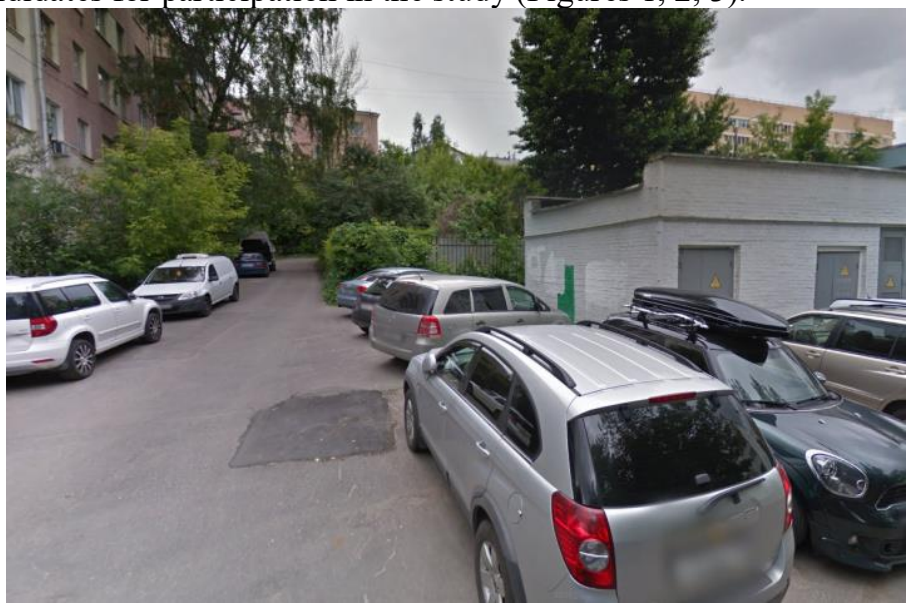

Fig. 1. Moscow, «Budyonovskij-village» 


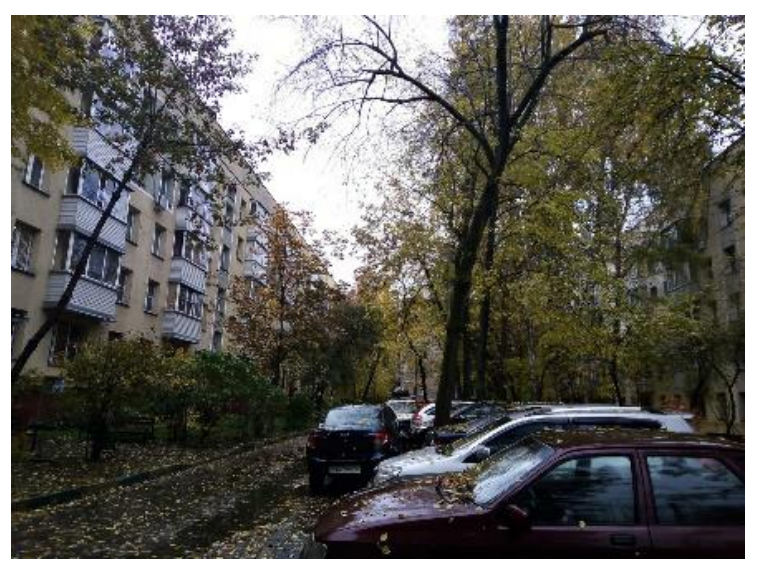

Fig.2. Moscow, 19 Lyublino microdistrict

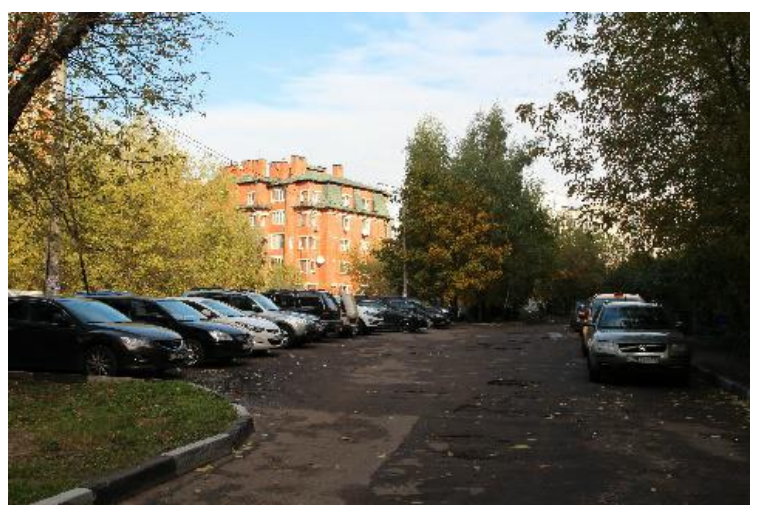

Fig. 3. Balashikha, «Pole-chudes»

Since the issue of reorganizing dense residential areas saturated with public, business and cultural facilities is of wide practical importance and also has investment attractiveness, a part of the territory of the Basmanny district was selected to conduct a project experiment on the reorganization of the territory based on the principles of pedestrian and NITS accessibility Central Administrative District of Moscow (Fig. 4, Fig. 5, Fig. 6) with a total area of 83 hectares.

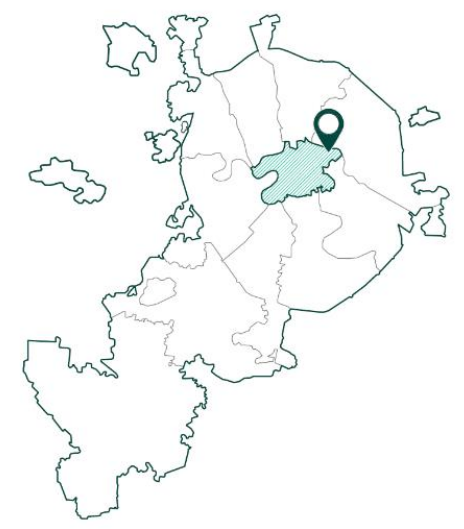

Fig. 4. The location of the study area on the plan within the boundaries of Moscow 


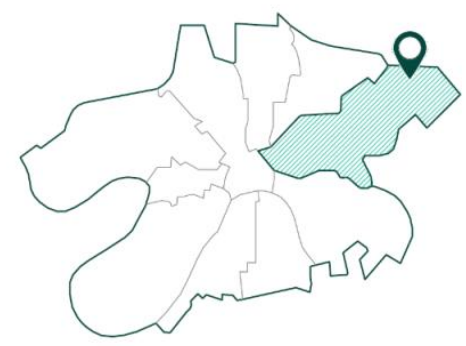

Fig. 5. Location of the study area on the plan within the boundaries of the Central Administrative District

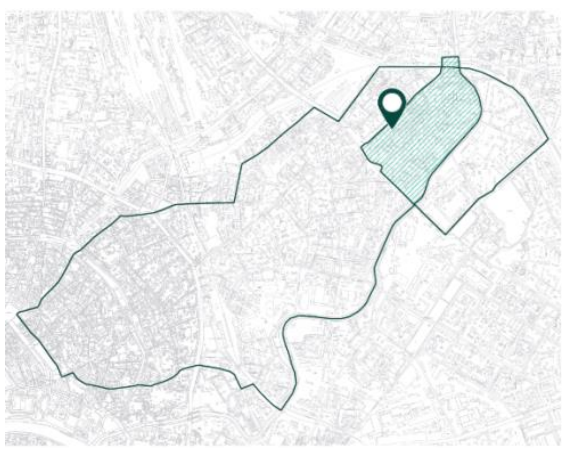

Fig. 6. Location of the study area on the plan within the Basmanny region

Based on regional standards for urban planning in Moscow and MGSN 1.01-99 "Norms and rules for the design of planning and development of Moscow." a calculation was made of the regulatory needs for urban infrastructure and an analysis of the existing situation.

During the pre-project analysis, it was found:

1. The residential area includes several residential quarters of different building periods, built based on various regulatory requirements.

2. The building density is $5634.58 \mathrm{~m} 2 /$ ha

3. The need for places in kindergartens and secondary schools is fully satisfied.

4. There is a calculated and actual shortage of places for the permanent and temporary storage of personal vehicles.

5. The percentage of green territories of the territory does not comply with regulatory values.

6. Physical deterioration of infrastructure objects is observed (broken paving slabs, cracks in the asphalt, numerous "patches" on the driveways and entrances to buildings, outdated equipment for various sites on the territory).

7. The network of pedestrian and LSPV communications is not developed, and the existing one does not meet the requirements of the movement of people with limited mobility.

8. Security requirements for courtyard areas (parking at playgrounds, poor lighting) are not provided.

9. There are 6 objects of the cultural heritage of regional and federal significance, public objects (including 2 higher educational institutions), as well as many objects of cultural and public and trade purposes. The presence of cultural heritage protection zones complicates the reorganization of the territory.

Thus, the territory under consideration is fully satisfied with the criteria mentioned above. 
Based on the results of the territory survey, a scheme of existing land use was drawn up and an analysis of the distribution of territorial resources by the functional purpose of the territories was carried out.

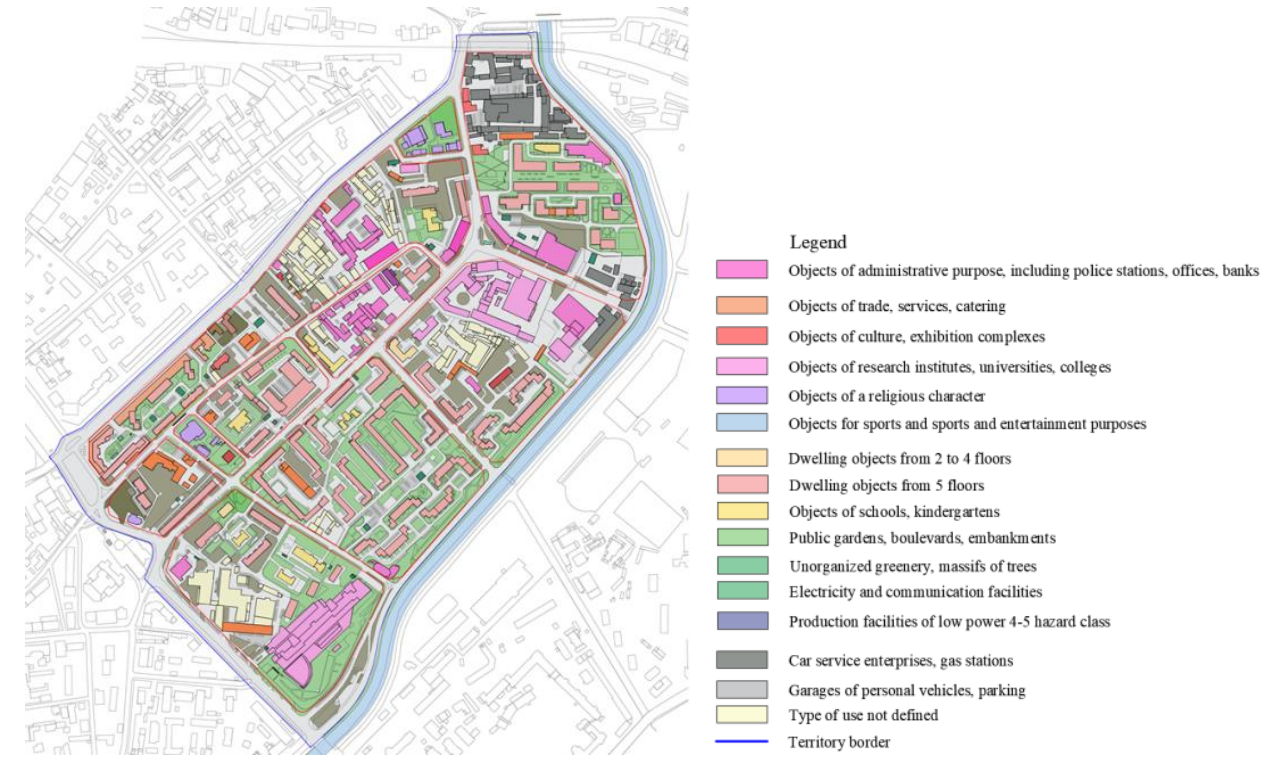

Fig. 7. Scheme of existing land use

\section{Results}

Based on the results of the analysis, a project proposal was developed to reorganize the territory of the district based on the principles of pedestrian and LSPV accessibility and taking into account the normative intensity of use of the territory. All tasks are implemented

Table 3 shows the design proposals for three residential quarters and the residential district as a whole. During the project experiment, the area occupied by driveways and car parking in the areas of the "Budyonovskoye Village" quarter (more than 4 times) and "Russian Venice" (more than 7 times) changed significantly. To comply with the requirements of the standards of urban planning for the residents of these quarters, newly constructed underground parking lots are provided.

In the quarter "Residence of Architects", built taking into account modern urban planning requirements, project improvements were not carried out. The quarter planning project provides for the storage of personal vehicles in the underground car park. Due to the freed-up territorial resources, the area occupied by the infrastructure for the LSPV and pedestrian traffic has been increased, children's, sports and business facilities, and recreational facilities for adults have been placed.

For the territory of the residential district, the project proposal is presented in Figure 8, the organization of traffic routes for the LSPV and pedestrian routes in Figure 9. In the whole region, the scale of changes in the balance of territories is not as significant as in the territories of residential quarters. Due to the reduction in the area of asphalted territories for servicing vehicles, there has been an increase in the area of green spaces and the area occupied by communications for pedestrians and LSPV. 
Table 3. Comparative characteristics of residential areas within the boundaries of a residential area

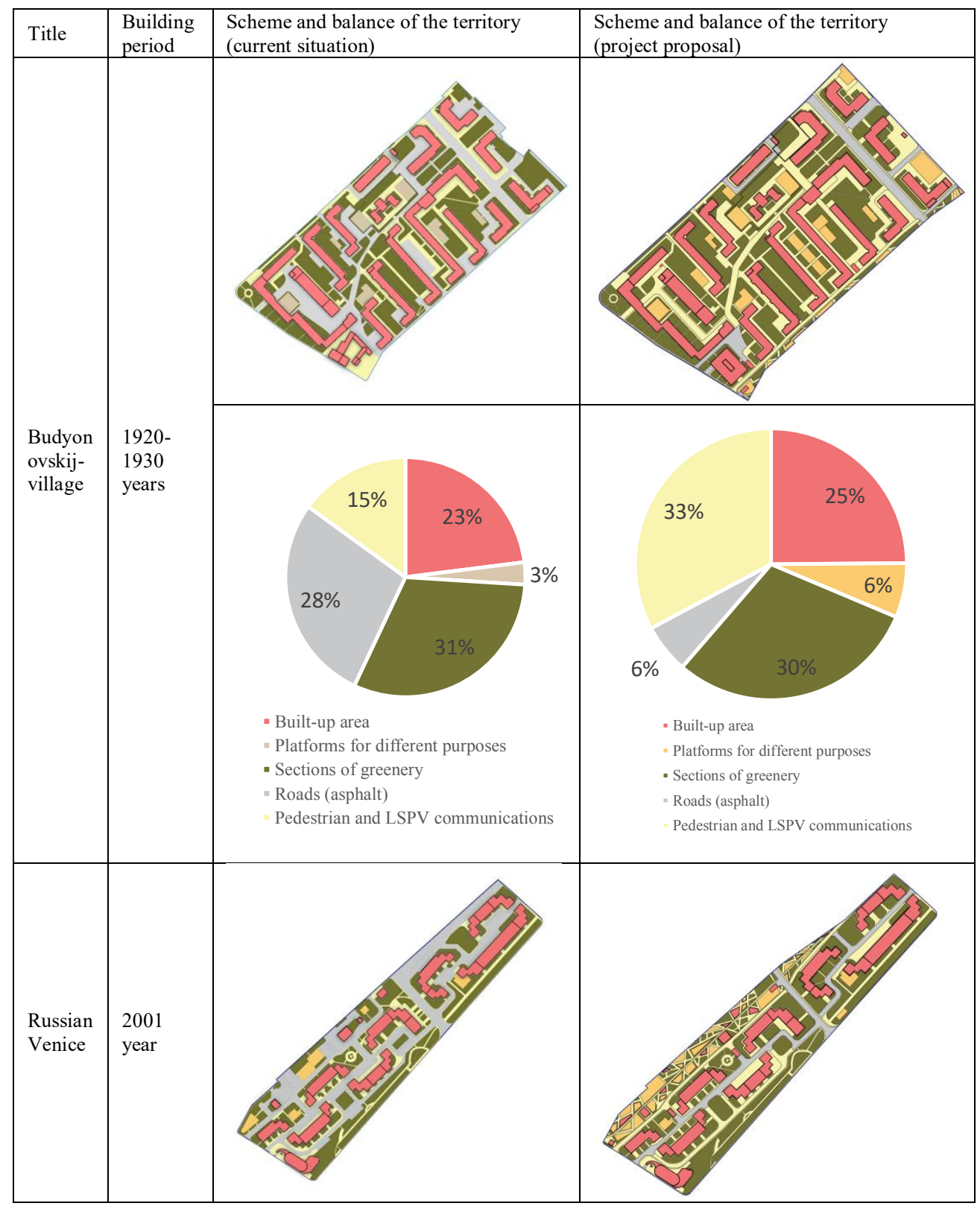




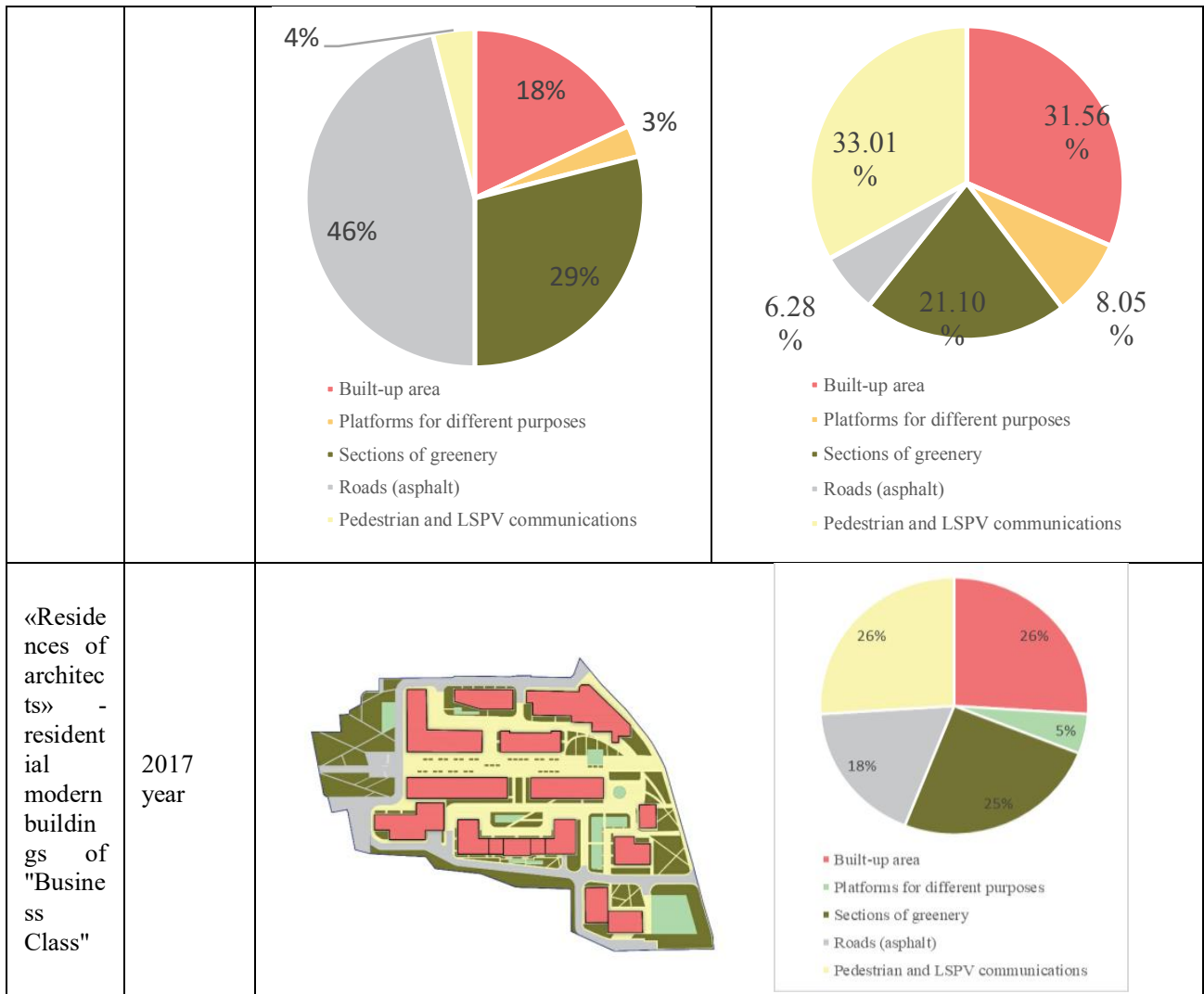

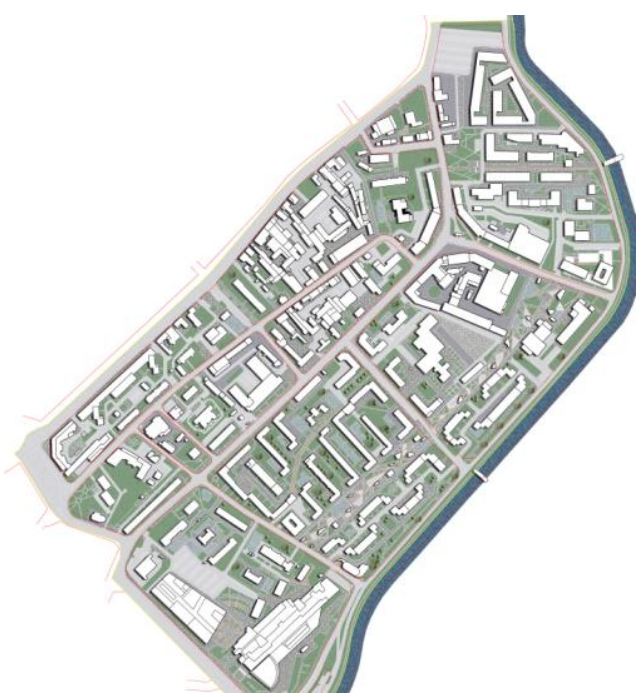

Fig. 8. The scheme of the architectural and planning organization of the territory (design proposals) 


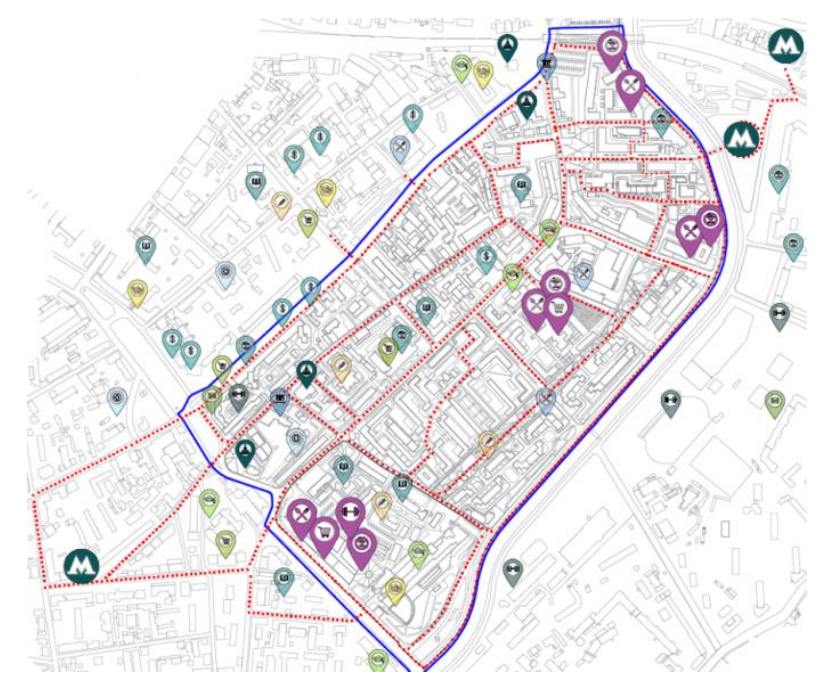

Fig. 9. Scheme of traffic organization of LSPV and pedestrian routes

According to the project proposals, the area of territories occupied by green spaces was increased by $5 \%$, and the coverage for LSPV infrastructure and pedestrian traffic - by $7 \%$, due to the reduction in the area of roadways and parking places by $12 \%$. (Figure 10, Figure 11). The required number of storage places for private cars is located in underground parking lots.

- Built-up area

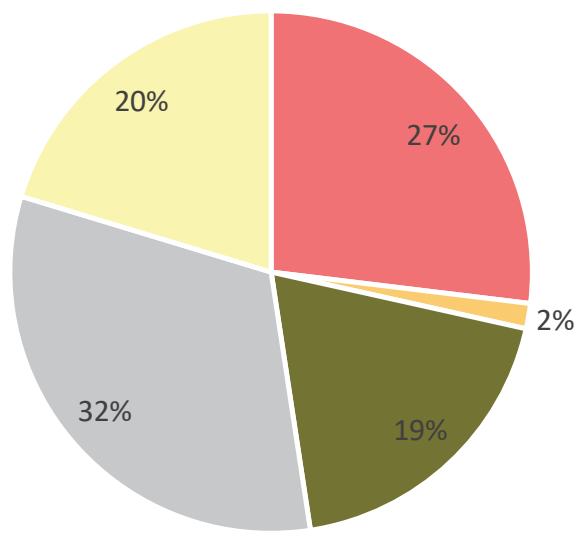

Fig. 10. Territory balance (Current situation) 


\section{- Built-up area \\ - Platforms for different purposes \\ - Sections of greenery \\ - Roads (asphalt) \\ Pedestrian and LSPV \\ communications}

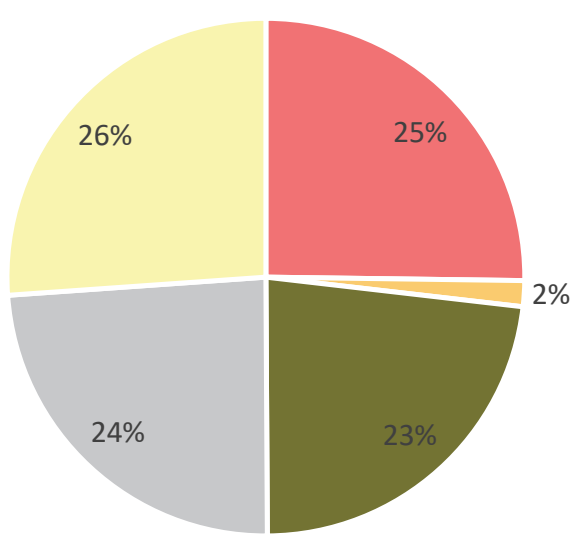

Fig. 11. Territory balance (Project)

\section{Discussion}

Thus:

1. One of the possible appropriate directions for the implementation of the reorganization of residential elements of the planning structure due to these advantages may be a direction that involves the creation of comfortable and safe traffic routes for pedestrians and LSPV users.

2. For a systematic approach to the reorganization of residential areas with a focus on walking and using LSPV, the basic principles of designing a residential environment are formulated. The use of these principles will allow to exclude errors in the arrangement of pedestrian paths and thereby will contribute to the involvement of the main masses of the resident and the daytime population. Due to the low-quality index of the urban environment in Russia, which reflects the physical and moral depreciation accumulated over the past decades in most residential areas, selection criteria were formulated for areas to be reorganized as a matter of priority and based on the principles of pedestrian accessibility and accessibility on LSPV. In conditions of dense development of residential areas, the volume of territorial resources that can be released to implement comfortable and safe routes on LSPV and pedestrians becomes an important factor. During the design experiment, it was found that for a built-up residential area in the central part of Moscow (Basmanny district) with parameters: built-up area - 22.4 hectares, built-up density $5634.58 \mathrm{~m} 2 / \mathrm{ha}$, provided that the regulatory parameters of the living environment are possible about $12 \%$ of the land resources used to service personal vehicles possess transformations.

In this regard, the question naturally arises of planning capacity and flexible transformation of individual elements of the planning structure of residential areas in modern urban planning conditions, determined by the reserve of territorial resources possible for redistribution.

Further research requires additional design experiments and a typology of residential areas to be reorganized with a focus on walking and using LSPV.

\section{Conclusions}

In the course of the study, the basic principles of arranging densely built-up residential 
areas with a focus on mass pedestrian movements and movement on low-speed individual vehicles were formulated. However, not all residential areas of the elements of the planning structure should be reorganized based on these principles. The article proposes the criteria that are the basis for the selection of territories for priority reorganization. During the project experiment, the percentage of territorial resources that could be redistributed to equip comfortable and safe pedestrian and low-speed individual vehicles was established.

\section{References}

1. L.H. Jenny. Northwest Economic Research Center (NERC) (2016)

2. Local Policies and Practices That Support Safe Pedestrian Environments (2016) (Access date: 15.02.2020) URL: www.TRB.org

3. Pilot Project Evaluation Summary, (SFMTA) (2014). (Access date: 15.02.2020) URL: http://sfpark.org/wp-content/uploads/2014/06/SFpark_Eval_Summary_2014.pdf.

4. A. Steve. Walkability. Scoping paper. (2005) (Access date: 15.02.2020) URL: www.abley.com.

5. Guide Information for Pedestrian Facilities (2013) (Access date: 18.02.2020) URL: www.austroads.com.au.

6. Pedestrian Environment Review System (Transport Research Laboratory) (2009) (Access date: 18.02.2020) URL: https://trlsoftware.com/

7. A. Halabya, K. El-Rayes. Journal of construction engineering and management, 146(1), 04019088 (2020)

8. D. Shoup. Transport and Sustainability, 5, 87-113 (2014)

9. A.Y. Davis, B.C. Pijanowski et al. Land Use Policy, 27(2), 255-261 (2010)

10. C. Lee, Knapik, M. Keough. Journal of transport \& Health, 7, S51-S51 (2017)

11. W.E. Marshall, D.P. Piatkowski et al. Journal of Transport \& Health, 1(4), 326-340 (2014)

12. K. Witten, T. Blakely et al. Environmental Health Perspectives, 120(7), 971-977 (2012)

13. Can the built environment reduce health inequalities? A study of neighbourhood socioeconomic disadvantage and walking for transport Health \& Place, 19, 89-98 (2013)

14. K.Sundquist, U. Eriksson et al. Study Social Science \& Medicine, 72 (8), 1266-1273 (2011) DOI: 10.1016/j.socscimed.2011.03.004

15. T.J. Pikora, B. Giles-Corti et al. Medicine and Science in Sports and Exercise, 38(4), 708-714 (2006)

16. L.D. Gunn, S. Mavoa et al. Designing healthy communities: creating evidence on metrics for built environment features associated with walkable neighbourhood activity centres.

17. A. Keyvanfar, S.M. Ferwati et al. Sustainabiliy, 10(4), 1035 (2018)

18. The Economic Benefits of Sustainable Streets New-York City Department of Transportation. (Access date: 15.02.2020) URL: https://nacto.org/wpcontent/uploads/2016/05/2-6_NYCDOT-Street-Design-Manual-2nd-ed-ch-2_2015.pdf

19. D. Flusche. Advocacy Advance Bicycling Means Business. (Access date: 15.02.2020) URL: www. bikeleague.org/sites/default/files/Bicycling_and_the_EconomyEcon_Impact_Studies_web.pdf 
20. F. Küster, B. Blonde. Calculating the economic benefits of cycling in EU-27 (Access date: 15.02.2020) URL: https://ecf.com/sites/ecf.com/files/ECF_Economic-benefits-ofcycling-in-EU-27.pdf

21. O.Y. Leptyukhova. Conf: SCTCGM 2018 - Social and Cultural Transformations in the Context of Modern Globalism LVIII

22. E.M. Cepolina, Menichini et al. Transportation research part F-traffic psychology and behavior, 58, 365-381

23. P. Christopoulou, M. Pitsiava. Social and Behavioral Sciences, 48, 1691-1701 (2012)

24. A. Devlin. Measuring the Quality of the Pedestrian Environment: Towards an appropriate assessment methodology (2013) (Access date: 14.02.2020) URL: https://therenewedcity.files.wordpress.com/2008/03/ped-los-final-draft.pdf 